\title{
Criminalising Football Fans In an Age of Intolerance
}

STUART WAITON 


\section{Introduction:}

It is clear that the individual who persecutes a man, his brother, because he is not of the same opinion, is a monster. Voltaire, The Philosophical Dictionary

There is a strange obsession with football today. If someone had told us in the 1980s that fans would be being imprisoned for singing unpleasant songs and players would be dragged through the courts for insulting one another on the pitch, we would most likely have laughed. Back then the over policing of football fans took the form of mass policing, the intimidation of away fans to and from games and the caging of spectators - a development that ultimately led to the Hillsborough 'disaster'. Today in contrast, the policing of games, where there is almost no violence, has taken a peculiar turn, with language, and the presumed politically incorrect attitudes of fans, being continuously targeted by both the football authorities and also by politicians and the law. The purpose of this chapter is to explain how and why this has happened.

In Scotland, where I have now lived for 23 years, I was recently involved in a campaign to oppose the criminalisation of football fans. Unusually, football supporters themselves (noticeably Celtic and Rangers supporters) started their own campaigns and began to protest about the criminalisation of fans, with banners at games, periods of self-censored silences and even rallies and marches to matches. Despite the usual bluster in the press about the problem of sectarian fans, a significant number of liberal critics also came out and opposed new legislation targeted at fans, labelling it as authoritarian, as something that made a mockery of the law, and as an example of illiberal intolerance. ${ }^{1}$

The above campaigns and comments related to the proposed Offensive Behaviour at Football and Communication Bill, a bill which became law in 2012 and which expanded the scope and range of potentially offensive remarks that could be targeted by the police at games.

There were many curious aspects to the emergence of and promotion of this new law: the interconnected discussion about offensive behaviour and violence, at a time when violence at games in Scotland is minimal, and the heightened discussion about the problem of sectarianism in Scotland - 'Scotland's Shame' - at a time when religion means very little to most people in Scotland and when the 'sectarian' politics associated with the conflict in Northern Ireland and with the Old Firm in Glasgow, has likewise, become insignificant to public life. On top of this, we had a law that targeted only football fans - and consciously did not target other more 'cultured' forms of offensiveness, like comedians, artists or writers ('real' writers not the Facebook kind). Football fans and their offensiveness was overtly targeted as being a special case, as different to other forms of offensiveness, and needing specific and intensive laws and forms of policing to deal with it.

Perhaps most problematically, we now had a law in Scotland that could be used to target anything that a 'reasonable person' would find offensive at a football match, and yet, football, in many respects is all about being offensive. Instinctively, as football fans, we know this. Indeed the tribal passion of the game, the anger, the chanting and shouting and even the overt aggressiveness at times, are all part and parcel of the 'beautiful game'. Being a football fan is more often than not an 
agonising experience; it is also an exhilarating activity, a place where grown men act like lunatics for 90 minutes, sing, shout, swear and scream at officials, players and opposition supporters. It is a walled-in space where for over a hundred years huge numbers of mainly men have gone and offended one another on a weekly basis. This makes it all the more peculiar that this new law passed in Scotland potentially makes it illegal to simply be offensive at football. In many respects being offensive is football.

But herein lies the problem. In a world that demands 'Respect', football fans (and indeed players) have increasingly come under the spotlight.

It is worth pointing out, for anyone who missed what was happening in Scotland in 2011, that the targeting of offensiveness at football became the Scottish government's number one priority. In fact, it was such an urgent issue for the first minister Alex Salmond that the Scottish National Party led government attempted to get the Offensive Behaviour Bill passed in a matter of weeks using emergency legislation procedures. This was an unprecedentedly short and anti-democratic length of time for such a piece of legislation and was opposed by many groups including the Equalities and Human Rights Commission who argued for the necessity of a 'broader consultation process', which was eventually granted. ${ }^{2}$

Despite the fact that there was already a significant body of law to target offensiveness, and specifically racism and sectarian, in Scotland, much was made of the need to 'do something' (more) about this problem following the so called 'game of shame' between Rangers and Celtic in March 2011. The game itself (not unusually) resulted in three red cards and a spat between Celtic's Neil Lennon and Rangers assistant manager Ally McCoist. Interestingly, it was this behaviour by players and managers, rather than fans themselves that was used as a launch pad for Strathclyde Police chiefs and Alex Salmond to call a football summit to tackle what was presented as a huge problem of sectarianism surrounding Old Firm fixtures.

Focusing on the problem of sectarianism at football the Community Safety and Legal Affairs Minister Roseanna Cunningham, explained that 'Racism, bigotry and sectarianism are not welcome in Scotland, it is totally unacceptable, and those who perpetuate this hatred will be punished through the full force of the law'. There was she argued, 'no place for bigots in a modern-day Scotland'. From now on Cunningham warned, 'anyone who peddles sectarian hatred - in any football stadium in Scotland, on the way to or from a game, or hiding behind a computer screen - could now face up to five years in jail'. ${ }^{3}$

Other proposals included: a new anti-sectarian police unit for football matches; new codes of conduct for players, coaches, officials and supporters; off-sales bans for Old Firm matches; new listening equipment for games to identify offensive songs being sung; and modern CCTV cameras carried by police officers to observe crowds and crowd behaviour. Many of these proposals have already been implemented, making football fans in Scotland one of, if not the, most scrutinised sections of British society.

However, political interest in football is not peculiar to Alex Salmond, the Scottish first minister, or to the SNP government in Scotland - far from it. Football has become, for want of a better term, a political football. David Cameron, for example, 
perhaps following the lead of Alex Salmond, called his own 'summit' on football to discuss racism and homophobia in the game. We mustn't go back to the bad old days of 1980s racism, Cameron explained. The sequence of events that triggered this emergency summit, set up by the prime minister of Britain, related to a football player calling another player an insulting name and then the same player refusing to shake the offended player's hand when told to do so. The event was discussed in the context of racism, which transformed it into a national, and indeed an international issue, and yet for some this was a playground event, simply a form of name calling.

The Suarez-Evra affair followed weeks of news stories about a similar incident between John Terry and Anton Ferdinand. Suarez was banned for eight games for calling Evra a name, Terry on the other hand was officially charged by the police for a public order offence for doing the same to Ferdinand. He also lost the England captaincy despite not having been to court, and then came the resignation of the England manager Fabio Capello whose advice to keep Terry as captain was ignored. But more was still to come. We had had a ban, a police charge and court case, next we got a weeping apologetic young man from Swansea imprisoned for eight weeks for being racist about Patrice Muamba on Twitter.

In Scotland, using existing legislation to target offensive words, Stephen Birrell, another online idiot, was imprisoned for eight months for writing insulting (nonthreatening) words about Celtic fans. Birrell apparently hates Fenian scumbag 'tattie farmers', and because he wrote about this on Facebook, Sheriff Bill Totten argued that he had committed a hate crime which would not be tolerated by 'the right thinking people of Glasgow and Scotland'.

Commenting upon the sentence, Alex Massie observed that this imprisonment for nothing more than writing unpleasant comments about people was a thought crime and a, 'shameful moment that demeans the country far more than anything said, sung or written at or about any damn football match' (Spectator $18^{\text {th }}$ October 2011).

Massie has a point, and when we compare the policing of fans in the eighties, for example, with today's criminalising of football supporters, we see it all too clearly. Then the focus of police attention was the actual violence of fans - the 'hooliganism' of 'yobs' at games; today, in comparison, it is more likely to be name calling at football grounds by fans that creates outrage, mass surveillance, awareness campaigns and demands for action by 'right-thinking people'.

For 'right thinking people' in both Scotland and England, imprisoning individuals for behaving in an incorrect fashion is understood and portrayed as the height of civilised behaviour. For many others, including many football fans, not only are the lengthy prison sentences being handed out to 'offenders' seen as harsh, but the criminalising of offensiveness is seen as simply wrong. Here there appears to be an issue of some significance; an issue that has not been clearly debated in society: Should offensive words be made illegal? Is this part of a progressive fight against bigotry? Or are these developments authoritarian and infantilising - creating a situation where grown men are treated, and encouraged to act like children who tell tales on one another?

Much of the debate in Scotland about the proposed Offensive Behaviour Bill was posed in terms of how this new law would help to create a 'modern tolerant Scotland'. 
But can these developments be understood as having anything to do with tolerance, and what does tolerance mean today if it results in people being imprisoned for the things they say rather than the things they do? This is one of the key questions being addressed in this chapter. It is an issue that has historic significance in terms of our understanding of freedom and indeed with the understanding of democracy itself.

In Scotland the speed with which an emergency summit about sectarianism and offensiveness in football was called, and the speed with which the government attempted to get the law passed, all suggested that Alex Salmond and the authorities were already geared up to 'fight intolerance' and to 'stand up against hate crimes'. In the UK, opposing racism and in Scotland opposing 'racism and sectarianism in all its forms' have become mantras at a time when there is very little evidence of any increasing problem regarding these issues. When Roseanna Cunningham stood up to denounce the shame of sectarianism in Scotland, for the vast majority of people this sounded entirely reasonable. But that is because nobody in Scotland stands up to defend sectarianism. Indeed, as Professor Steve Bruce, and the co-authors of Sectarianism in Scotland have argued, in any way you want to measure it, the problem of sectarianism in Scotland is massively exaggerated. Ultimately they argue, 'sectarianism' (to the extent that you can call it that) in Scotland, is almost entirely based upon the football rivalry between Glasgow Ranger and Celtic (Bruce et al. 2004).

But again we have a problem here, because football fans are sectarian. That's the whole point about being a fan. You are tribal and irrationally loyal, and when the opposition arrives (especially after a dodgy tackle and a 'ridiculous decision by the referee') you 'hate' them, you mock them and you taunt them with songs that ridicule their tradition. What then does 'fighting sectarianism' in Scottish football actually mean?

If we stand back from the rhetoric of it all, the shouts of 'racist', 'bigot', 'shame' and so on, we need to ask why the pantomime of hate at football has become a major political issue both North and South of the border? The argument made here is that the elevation of issues regarding racism and sectarianism in football has nothing to do with the behaviour of fans and everything to do with the nature of our (post) modern authorities.

\section{The changing nature of 'scum' in football}

\section{The ideas of the ruling class are in every epoch the ruling ideas.} Karl Marx, The Germany Ideology

Following the so called 'disaster' at Hillsborough the Sun, notoriously, and to their cost, lied about Liverpool fans robbing the dead and urinating on injured police officers. This resulted in shops in Liverpool refusing to sell the paper, and to this day many Liverpudlians still refuse to buy the Sun. The Sun had miscalculated, but in reality was simply pedalling the accepted conservative wisdom about 'scum football fans' that had been relentlessly reproduced throughout the eighties. As the Independent on Sunday later noted, even the editorial of the 'respectable' Times newspaper, for example, earlier in the 1980s, had discussed football as a 'slum sport 
played in slum stadiums watched by slum people' (Independent on Sunday $14^{\text {th }}$ August 2011).

Elitist contempt for football fans was not specific to the 1980s. Indeed, ever since football developed as a mass spectator sport in the late nineteenth century, there have been snobbish outbursts about the sort of people who watch this 'slum sport'. The founder of the Scout movement Robert Baden-Powell, for example, moaned about the 'vicious game' watched by 'Thousands of boys and young men, pale, narrow-chested, hunched up, miserable specimens smoking endless cigarettes...hysterical as they groan and cheer in unison with their neighbours' (McArdle 2000: 67). Football stadiums themselves were designed and remained as dilapidated sheds for much of the twentieth century, usually containing a seated area along the side of the ground for the better off spectator, while the rest of the fans were allowed to huddle at either end of the pitch often without any protection from the elements.

Elitist contempt for football fans may not have been new, but for much of the postwar period it was rarely expressed openly, and was not a political issue of any significance. Through the seventies and eighties this changed, and an intense concern about the violent nature of football hooligans emerged as a problem to be addressed. As a number of critical writers argued at the time, extreme events and unexceptional incidents were interpreted and highlighted because of the wider concerns and preoccupations of the Conservative establishment. In the 1970s, vandalism and violence of fans was redefined through both academic and governmental discussions about the problem. As Giulianotti explains in Football Violence and Social Identity, this specific social problem was now part of the governments' consciousness, and was an issue that began to be addressed in terms of social control measures (Giulianotti, Bonney and Hepworth 1994: 1-8).

'Hooliganism' was not a fantasy or a mere baseless social construction, however the interpretation of the problem of some football fans, and indeed the labelling of the 'hooligan problem' can only fully be understood with reference to the political tensions and wider social problems of the time. The emergence of the first piece of legislation specifically targeted at football fans, the Sporting Events (Control of Alcohol) Act 1985, for example, should be situated within the wider law and order drive that had developed out of these tensions in the 1970s.

At the same time as football fans were being separated and labelled as different, they were also targeted as part of a wider group of 'deviants' in society, loosely known as the 'enemy within'. The recently released film, The Iron Lady, looking at the life of Margaret Thatcher who was prime minister in the 1980s, is a useful reminder about the confrontational nature of politics at this time. A time when mass strikes and militant trade unionism existed, when inner city riots by black people erupted that made the 2011 riots look like a tea party, and a time when the IRA were bombing not only the mainland, but were killing members of the British government. At a time of deep divisions within the country, conservatives targeted all these different groups and labelled them as violent deviants - what became known as the 'enemy within'. Increasingly, an aggressive law and order approach was adopted to counter this 'enemy' and new laws were developed to increase the power of the police. 
At the 1985 Conservative Party Conference, for example, the Home Secretary Douglas Hurd, after receiving a standing ovation for his praise of the aggressive policing of the riots, promised a new law to target trade union pickets and hooligans. Here, the trade union militant and the hooligan were presented as part of the same problem, with both being used to sully the name of the other: Trade unionists were hooligans, and hooligans were part of the leftist problem of violence, criminality and irresponsibility that was destabilising society: The result was the Public Order Act 1986.

Defined as part of a 'mob' in society, football supporters became heavily policed. Away supporters in particular, were at times, treated as a virtual invading army, escorted to and from grounds by lines of officers and welcomed to the ground by riot vans, police dogs and mounted police. Fans in general also became the guinea pigs for new forms of surveillance and crowd control mechanisms, with CCTV and ID cards first proposed as a way to regulate football supporters.

Within the Public Order Act provision was made for arresting people who used threatening, abusive or insulting words or who acted in a way or said things that could cause harassment, alarm or distress. However, unlike today, this understanding was based less on a concern about the harm done to individuals, than upon a concern to defend society's values, the peace of the Kingdom, British standards of behaviour and so on. It was a Conservative and moral use of the police and law to control the mob of pickets or the 'yob class' who went to the 'slum game played by louts in front of hooligans', as one Tory Lord described football and football fans at the time. ${ }^{5}$ It was also part of a political, and at times, physical battle with the 'enemy within' who were criminalised and faced significant limitations on their freedom of movement something that both pickets and football fans experienced.

As we moved into the 1990s, the deposing of the prime minister Margaret Thatcher, by the Conservative Party itself, signalled a change. Now collective and class based politics began to be replaced by more individually oriented concerns and the 'public' both became and were treated as a collection of individuated and insecure individuals with policies that increasingly focused upon issues of health (and most particularly in relation to football) safety. For example, the Taylor Report of 1990 which looked into the Hillsborough event argued that there needed to be a 'higher priority given to the safety and well-being of spectators', with emphasis being placed on the comfort and safety of football fans (Garland and Rowe 1999: 225). The Football Licensing Authority and the new football safety officers also became central to match day preparations. More widely, the question of safety grew tentacles and became a prism through which the game on and off the pitch was examined.

With the expansion of this culture of safety, the operational principle that emerged appeared to be predicated upon three assumptions: firstly that each individual needed to be kept safe; secondly, that other people should consequently be treated as possible sources of risk; and finally, that individuals were vulnerable and needed a greater level of protection than previously. Increasingly, the role of the authorities was to keep us safe. Safe not only from violent hooligans, but safe also from the person sitting next to us who may be drunk or smoking, or indeed offensive. 
Despite the less aggressive form of policing at games in the nineties, and a decline in the old elitist rhetoric targeted at 'slum people', legislation to control fans nevertheless continued and expanded. Following the Football Spectators Act of 1989 which proposed ID cards and passed what were to become Football Banning Orders (FBOs), the Football (Offences) Act 1991 was passed. This was a particularly tough law and order act which led to an increase in sentences for 'hooligans', set up the Football Intelligence Unit, made it a specific offence to throw an object onto the pitch, took a zero tolerance approach to anyone going onto the pitch and, most importantly in terms of how the policing of fans was to change, the act also criminalised racist or indecent chanting in a stadium.

In both acts, more than a hint of the old conservative focus upon football fans as a public order problem remained, but now the discussion began to shift towards a concern about safety. One way this discussion developed was around the notion of making football 'family friendly'. For David McArdle (2000: 82) the criminalisation of indecency was understood to be nothing more than 'an attempt to sanitise the match day experience for the edification of a new breed of consumer'. Still within the rubric of 'clamping down on slum people', these new laws began to stretch further out into areas of etiquette and language. Consequently, football fans once again became the guinea pigs of a new regulatory approach to public life, an approach that was increasingly legalistic but perhaps more importantly also worked through a new type of moralising about behaviour and offensiveness.

A kind of customer care approach rather than public order enforcement developed. Of course, the ideal football 'customer' was a particular type of person, someone acceptable to 'families' - to women and children - the assumption being that women and children do not like rowdy, crude, foul-mouthed men at football games (my wife and children wouldn't agree). Towards the end of the century a new 'correct' fan culture was being encouraged, with the Sunday Mirror launching a campaign to, 'cut out the foul language which is driving families away from the game' (Sunday Mirror $3^{\text {rd }}$ January 1999). This was based on a highly moralised perception of 'families' and was encouraged by the FA who launched a poster campaign instructing fans to, 'Keep the Passion, Lose the Language'.

Opposition to the more sanitised and commercialised form of football culture also developed at this time, with concerns about wealthy owners, price structures, the criminalisation of standing fans and a general concern about the way 'terrace culture' was being artificially manipulated and sapped of an 'authentic' fan culture. In Moving the Goalposts, Ed Horton argued that there was 'a policy of social cleansing, of making football suitable for the better-off by the simple means of removing the lower order from the stands'. In a similar vein, a Manchester United fan in United We Stand, complained of the 'antiseptic family values' and the 'deproletarianisation' of the game, while books of 'traditional' football chants were printed in an attempt to save the game from 'gentrification' (Brick 2000: 161).

This romantic reaction to the 'gentrification' of football was, in part, a reaction to the growing regulation of fans. However, key aspects of these new regulations were either ignored or endorsed by these critics. Sociologist Carlton Brick, for example, interestingly observed that books like You're Not Singing Anymore: A Riotous Celebration of Football Chants and the Culture that Spawned Them, were often 
sanitised themselves and endorsed what was to become a new form of linguistic correctness. In You're Not Singing Anymore, the author explained his own censorship of certain unacceptable songs, explaining that:

Many chants have been omitted [from the book] due to their racist or sectarian content. Some, such as the songs about the Munich Air Disaster that have been directed at Manchester United fans, are absent on grounds of common decency (Brick 2000: ibid).

In what appears to fit comfortably with the newly emerging official etiquette, those who were critical of the sanitisation of football appear to have not only accepted but to be promoting the same line as the authorities, one which includes the censoring out of offensive words and songs from the game.

As Brick argues:

Here lies the greatest irony. Whilst formally oppositional to the new moralities of the football stadiums, the discourses of resistance are an implicit acceptance and appropriation of the new discourses of regulation that have been a feature of the policing and regulation of post-Hillsborough football fandom (ibid).

The former self proclaimed football hooligan Dougie Brimson, who set up the Football Party to stand up for 'real' fans, similarly argued that we need to seek, 'the removal of intimidation in all its forms, be it racial, verbal or physical' (ibid).

For Brick, the unquestioning acceptance of this new 'caring' and 'correct' form of behaviour promoted in football was a problem, one that implicitly accepted a new form of regulation, control and even criminalisation of fans, for doing little more than singing unpleasant songs or behaving in an aggressive manner at games. Previously radical gender and race politics, Brick argues, under the auspices of the 'family friendly' game, were transformed into regulatory mechanisms for policing ever more aspects of fan behaviour.

By the late 1990s it had become the norm, across the (increasingly one-dimensional) political spectrum, to work on the assumption that any problem within football could, and indeed should, lead to a national governmental response. Using laws to resolve perceived social problems became the norm under New Labour resulting in the Labour government introduced the equivalent of one law for every single day they were in office (Waiton 2008: 82). Demonstrating a pride in this new legalistic approach to social policy and the rising criminalisation of fans, the Football (Offences and Disorder) Act of 1999 was celebrated by the Labour Sports Minister Tony Banks as the, 'toughest anti-hooligan legislation of almost any country in the world'. It was quickly joined by the Football (Disorder) Act 2000. The result was that it became even easier to arrest and prosecute football fans, and to be even tougher on them in the courts. Consequently, stronger laws on ticket touts, stronger laws on racist and indecent chanting and also more far ranging Football Banning Orders (FBOs) were introduced.

Interestingly, section 9 of the 1999 Act replaced section 3 of the Football (Offences) Act 1991 and now made it illegal for an individual to carry out racist or indecent 
chants. This appears to reflect a shift in how the problem of 'football hooliganism' was understood. Initially it had been made illegal to shout indecent or racist chants when in a group. The illegality was seen in terms of the 'mob' acting as an intimidating crowd and as such as part of a collective public order problem. However, through the 1999 legislation a lone individual could be arrested for the words he used, making it both easier to arrest someone, but arguably also reflecting the increasing importance being given to words themselves and the need to both protect people from these words and to punish anyone who uttered them. Rather than public order, the problem was understood as one of individual disorder: Of people who needed to be protected from offensive words and people who needed to be arrested for individual acts of offensiveness.

As the new millennium approached the elitist approach to football fans had changed. Perhaps most noticeably, reflecting wider trends in culture and politics, the new elite were increasingly cosmopolitan rather than nationalistic. Now waving the Union Jack and singing aggressive nationalistic songs at England games, for example, became more problematic. The new, preferred England fan would carry a St George's cross, or better still, ditch the flag and have it painted on their face while singing along to the official supporters' brass band that followed the team. If being nationalistic in the 1980s was for key sections of the British establishment normal, decent and even moral, by 2000 the new elite was more likely to see it, especially when carried out by working class football fans, as intolerant, offensive, potentially racist and even as a form of violence.

In many respects anti-racism became a mantra, and within football it became an unstoppable new mechanism for criminalising and regulating everyone connected with football; a new enforced etiquette.

In 2012 there was barely time for the dust to settle on one national news story about racism in football before another kicked off. From Blatter to John Terry to Suarez and Muamba the racialisation of the discussions surrounding football appeared to be increasing by the week. On Match of the Day, while discussing these issues, pundit Alan Hansen made the mistake of using the incorrect term 'coloured' to describe a black player resulting in the colour draining from the faces of his fellow presenters who realised his mistake. Discussing the issue of racism, Talk Sport's usually in-yourface presenter Adrian Durham noted, humbly and in acceptance, that he knew if he made just one 'slip of the tongue' on this issue he could expect to be washing dishes for the rest of his life.

For many anti-racists in the 1980s the fight against racism meant campaigning against deportations, fighting a political battle against racist immigration controls, or even a physical battle to stop violence against black and Asian families in inner city areas. By the end of the century and into the new millennium the 'battle' increasingly appeared to be with your own tongue, with words and 'offensiveness'. For critical race expert Christopher Kyriakides, there had been a metamorphosis in anti-racist activities, shifting away from a challenge of the authorities to become a form of policing used by the authorities (Kyriakides and Torres 2012: 55-80).

This is not to argue that nobody at football was being racist; some individual clubs have had an association with far right groups and with racism. However, there appears 
to have been a remarkable acceptance both within football and even academia that, firstly, there is a serious problem to be addressed that necessitates football fans being told not to be racist and, secondly, that the various official campaigns targeted at racism in football were unquestionably good.

One of the most interesting aspects of official anti-racist campaigns and debates about racism in football is that they have become more frequent at a time when racism in society is arguably declining. As football writer Duleep Allirajah notes, 'At a time when terrace racism has virtually disappeared, the campaign to kick racism out of football is everywhere. Why?' No serious writer on the subject argues that racism in football has got worse in the last two decades, indeed many writers note the opposite is the case..$^{6}$ As one football writer noted, the ironic thing is that when racism was commonplace on the terraces and when he was joining protests against Asian families being driven from their homes by racists or marching to the Trade Union Congress to protest against deportations, few people within politics or the media seemed to take any great notice of this. ${ }^{7}$ Contrast this with the 2000-1, a time when new laws were passed to increasingly police racism in football and to promote anti-racism at games and yet there were only 17 arrests for race related incidents in the Premier League that year. This was a slight fall from 23 the previous season. This may well be one incident too many, but this is 17 arrests out of a total of 13 million people who went to watch these games, a problem of significance for 0.0001 percent of football fans.

The significance of anti-racism as an unquestioned new form of regulation and policing is problematic. As Allirajah observed in 2001, whenever new anti-hooligan measures are introduced, anti-racism is now the standard justification used. ${ }^{8}$ To be a respectable Englishman you now had to be officially 'anti-racist' and to accept and even support the increasing use of CCTV surveillance and the tighter monitoring of fans in all grounds across the UK as part of the 'fight against racism'.

By 2012, the Equality and Human Rights Commission boasted that racial prejudice was now seen 'as a secular sin that is not to be tolerated'. Part of being British in the twenty first century, Mick Hume argues, is to be, and to be seen to be, anti-racist. For Hume, this official anti-racism is a new form of moralising. Ironically, it can be, and is, used to denounce foreigners, like the Spanish or East Europeans, who are seen as less anti-racist than we Brits. Of course, Hume notes, within Britain itself the new elite look upon the British white working class as the greatest sinners of all, a group who need to have the "etiquette of official anti-racism drummed into them at every opportunity'?

One of the important things about anti-racism today, Kyriakides argues, is that it now embodies the notion of 'unwitting' racism, a definition that emerged out of the Macpherson Report into the murder of Stephen Lawrence. This is a definition that lacks any relationship with politics, power or society, and transforms racism into an individual, psychological problem or one simply based on ignorance or a lack of awareness (Kyriakides 2008). This almost mystical form of racism, where you can be a racist without knowing it, reduces racism to behaviour and language, and crucially 'offensiveness'. If someone finds your words or actions racist and offensive - they will be recorded as being so, regardless of your intention. In many respects becoming an anti-racist was now akin to attending a finishing school, learning about how your unwitting use of words could be offensive, and being taught not to say the word 
'coloured'. Consequently, those in authority, those with power - in the media, politics, and law - became the arbiters of this new etiquette.

Sadly, 'radicals' who once challenged the authorities over their demonisation and criminalisation of football fans are often the most authoritarian today. Garland and Rowe believe that anti-racism in football has not gone far enough and argue for the need to adopt more vociferously the Macpherson definition of racism. Using the example of Jason Lee - the footballer whose dreadlock hair cut led to the 'He's got a pineapple on his head' chant that was started by the comedians Frank Skinner and David Baddiel - Garland and Rowe argued that this was part of an elusive form of racism which pervades football and needed to be stamped out. As they argued, here we had a case of contemporary culture articulating, 'racialised themes in a coded manner that lacks overt racist language or references'. Remarkably, despite Skinner and Baddiel having no intention of being racist, and in fact being anti-racists, they became racist, as did fans singing the pineapple song, because Garland and Rowe decided this was the case. As Allirajah noted, 'In other words we are dealing here with a strain of racism so 'unwitting' that it is only discernible to trained sociologists'. ${ }^{10}$

The concerns about football fans had emerged in the 1970s and 1980s not simply because fans became more violent, but more importantly, the problem of hooligans was elevated as an issue by a conservative establishment battling with what they saw as an enemy within - a collective disruptive mob that was undermining good old fashioned British values and British society itself. Public disorder and the actions of the violent mob would be curtailed by the authorities getting tough and restricting the movements of various groups. At football, this resulted in a variety of heavy-handed measures being introduced, one being the creation of caged-in football fans. Hillsborough was the ultimate result of this.

By the turn of the century, football fans were still being heavily policed but now, through the language of safety and offensiveness, new forms of regulation emerged as the old established snobbery about 'slum people' intertwined with a new form of cosmopolitan elitism about the macho and racist nature of white working class fans. In many respects anti-racism replaced British jingoism as the default position for right thinking people. Ironically, anti-racism itself became very British. Into the new millennium the policing of racism in football increasingly became an accepted norm a new moral good, and yet still the evidence of this problem did not exist, with only 44 arrests taking place this season across England and Wales for the 37 million people who attended games. ${ }^{11}$

Key to this shift was a move away from the concentration on policing the movement of the mob towards a regulation of individuals' songs and chants. Initially, through the language of anti-racism, the policing of offensiveness emerged, opening the door to further demands that words be regulated and controlled in football grounds.

\section{Intolerant 'Tolerance'}

My duty to be tolerant towards the 'other' effectively means that I should not get too close to him, intrude on his space. In other words, I should respect his intolerance of my over-proximity. What increasingly emerges as the central human right of 


\section{late-capitalist society is the right not to be harassed, which is a right to be kept at a safe distance from others. Slavoj Žižek, Violence}

Looking back at the Scottish example, we find a situation where many football fans, find it incomprehensible that someone singing an 'offensive' song at a game could be imprisoned for five years. In an online petition I set up opposing the Offensive Behaviour Bill there are a variety of comments attacking this new piece of legislation, ranging from those who defend free speech on principle, to individuals who are simply outraged that money and police time is being wasted on this when there are 'criminals out on the street'. ${ }^{12}$

Much of the rhetoric defending new laws against fans comes in the form of opposing sectarianism. Like anti-racism in England, anti-sectarianism in Scotland, as Professor John Flint has noted, has become a new form of governing (Flint 2008). Indeed looking at the rise of the anti-sectarian industry, which largely developed from the year 2000, we can see that the previous first minster Jack McConnell had his own anti-sectarian moment, when he too stood tall as the true opposition to what he termed 'Scotland's shame'. Consequently for the last ten years a whole range of antisectarian initiatives in football, in schools and communities, in prisons, even in the Scottish Parliament (where members and staff can receive anti-sectarian awareness training), have been set up.

Opposing sectarianism is, like opposing racism, a new absolute, a viewpoint that all 'right thinking people', policemen and women, politicians, professionals, media pundits and so on, who want to get on in the world, must adopt. But like official antiracism, official anti-sectarianism has not emerged because of a rise in sectarianism amongst the people of Scotland, but because of the rise of an anti-sectarian elite. In other words it is the nature and attitudes of the elites in Scotland, rather than the punters, that has changed, thus elevating the significance of sectarianism in society.

John Flint's argument that anti-sectarianism became a new form of governing is important. However, it is more useful to see both this and the rise of anti-racism as part and parcel of the rise of 'tolerance' as a more general basis for governing society. When discussing the problem of sectarianism and offensiveness in football for example, Roseanna Cunningham relentlessly counterposed the ideas of the bigots with her progressive vision of what she called a 'modern tolerant Scotland'. Being tolerant incorporates both opposing bigoted ideas and more specifically today, opposing the use of words, songs, chants or symbols that will cause offence to certain groups and individuals. And it is this doubled edged form of tolerance that has resulted in football fans being targeted by the authorities in the last decade.

It is crucial, as the sociologist Frank Furedi has argued, to recognise that what tolerance means today is very different from its previous meaning (Furedi 2011). Having been the bedrock of the defence of free speech and the need to 'tolerate different beliefs and opinions', it has now come to mean the very opposite of this. Consequently, free speech has become regulated and criminalised as part of a process of enforcing 'tolerance of others'. Rather than respecting the freedom of people to speak their mind, we are instead encouraged to respect people's differences and not upset them by saying 'offensive' things. This new right not to be 'harassed', even verbally, has consequently become the basis of new laws; at the same time, there is a 
vast expansion in the policing of language, thoughts and behaviour that were previously seen as of no significance, or as something that grown adults were expected to be able to deal with. As the public comes to be seen as vulnerable and in need of protection from offensiveness, 'intolerant tolerance' comes to the fore.

Historically, tolerance was not about limiting free speech so as to protect the sensibilities of different groups in society. It was the very opposite of this, representing a rejection of state power over control of speech and behaviour and a belief that people's ideas, however repellent, should be tolerated. Developed through John Locke and later, John Stuart Mill, the idea of tolerance related to a principled defence of freedom of conscience, belief, and later on, behaviour. Freedom of speech was championed by classical liberals but this did not mean that there was an 'anything goes', approach to ideas and behaviour or that 'everyone's opinions and behaviour are equally valid'. Rather, tolerating free speech and behaviour, or not criminalising it, was coupled with the equally important belief that ideas and behaviour could and should be judged and challenged. You weren't expect to simply 'respect' other people's beliefs (or cultures), but the opposite, you were expected and encouraged to be judgemental, and to be free to challenge and even ridicule one another's words and deeds. The notion of tolerance was a liberating starting point for intellectual and moral contestation, development and improvement: Within a tolerant society, ideas and ways of behaving could be challenged, the truth sought and a more civilised society nurtured (Mill 1998).

For Mill, the principle was clear - as long as no physical or economic harm was done to an individual, ideas and behaviour should be tolerated - even, and indeed especially, ideas or forms of behaviour that you found abhorrent or upsetting. 'Wrong' ideas or behaviour were useful for Mill because they continually encouraged society to challenge them, thus strengthening the understanding of ideas across the populace. This was important not only for the free development of ideas and beliefs but also, and equally, for the development of individual moral autonomy. He who lets the world choose his plan of life for him, Mill argued, has no need of any other ability than that of imitation. But this is not the action of a man; it is merely the action of an ape. Part of the belief in the importance of personal moral development came from an idea that it was wrong to force beliefs onto people. The goal was to encourage a vibrant culture made up of autonomous individuals who were free to think and act and also to challenge one another's behaviour.

In a sense, as Furedi notes in On Tolerance, Mill wanted everybody to be a heretic to be a free choosing man - rather than a sheep, repeating the latest correct and inoffensive mantra. Accepting rather than punishing those whose views and behaviour you hated required strength and maturity, and most of all a belief in the importance of freedom. As George Orwell noted, if democracy means anything it is the right to tell people what they do not want to hear. ${ }^{13}$

Today, in comparison, the meaning of tolerance has been transformed. This has developed over many decades across the Western world, Furedi notes, with little discussion or clarification about what this thing tolerance now actually means. Tolerance means the opposite of what it used to. It is now about being nonjudgemental, about limiting hurtful speech and behaviour, about increasing state power to protect the people who are seen as fragile and vulnerable. It has become a 
personal characteristic, a badge of decency, disconnected from the idea of freedom or even thought. It has also become about 'respecting difference': not respecting individual freedoms as such, but 'respecting' statically-defined groups and identities. It has also become a form of politeness based on an understanding that these groups and identities are easily bruised by things we say, beliefs we have and types of behaviour we exhibit. Consequently, having offensive ideas or behaving in an offensive way is understood to cause alarm or distress and needs to be regulated or made illegal. Rather than tolerance being about individual freedom and the autonomy of individuals, it has become about respecting groups and group identities and protecting them from harm.

One of the many unintended consequences of this is that at the very same time that anti-sectarianism and anti-racism are relentlessly promoted, they lose any weight or depth of meaning - they become empty. Being 'against racism and sectarianism in all its forms' has become a mantra (repeated ad nauseum in the Scottish Parliament during the debate on the Offensive Behaviour Bill), disconnected from ideas or from real practice or grass roots campaigns. The students that I teach, for example, almost all claim to be against racism in all its forms, but have very different and indeed conflicting views about how we should relate to and treat immigrants. For them, as for the rest of society, being against racism and sectarianism is not an active thing, but is simply about being polite, not being offensive, not calling people names that might be hurtful. As Žižek comments above, it is about respecting the other's right not to be 'harassed'. ${ }^{14}$

New tolerant anti-racism and anti-sectarianism is a performance, it is nothing to do with what type of person you are, very little to do with your beliefs, and very much to do with your unthinking deployment of the correct terminology and proscribed codes of behaviour.

The changing meaning of tolerance has been focused upon here because it is one of the central reasons why anti-sectarianism became such a useful resource for the Scottish authorities in the new century. Tolerance had come to mean 'respecting difference'; it is a form of emotional correctness, an awareness of the sensitivity of others, of the potential hurtfulness of words. Over time, the engagement with this new form of tolerance has increasingly led to words being criminalised. By 2012, with the passing of the Offensive Behaviour Act, offensiveness in general was made into a policing matter. To be tolerant now meant arresting fans for uttering any words that 'right thinking people' found offensive.

\section{Conclusion}

Today politicians don't have much going for them. Not least of all in the realm of ideas, politics is a largely empty vessel. The battles of the eighties and the political 'sides' people took mean very little today, and the lack of passion and belief in political life is reflected in the dwindling membership or parties and the almost nonexistent party activists. As the leaders of the political parties get younger and younger one can't help thinking that 'youth' is attractive in politics because the younger they are the less tainted they are by simply being politicians. 
Modern day tolerance - or non-judgementalism and respecting difference - is consequently attractive to individuals and organisations that find it difficult to represent a common good, to represent a strong sense of national unity, or to encourage minorities to assimilate to $a$ culture. Defensively, society has adopted the stance of respecting 'cultures' and encouraging the construction of 'communities' while setting up a plethora of laws to protect people from hurtful words and behaviour.

The pantomime passion of crowds at football matches, within this rather anxious and unsure political climate have become a source of concern for the modern elite whose lack of political engagement with the public leave them with nightmares about 'stadiums of hate' occupied by the Sun reading masses. ${ }^{15}$

The behaviour of football fans has nothing to do with free speech in the classical sense. People are not speaking to one another at a game, they are shouting at one another. You do not have a discussion or a contestation of ideas; you generally just hurl insults and shout each other down. This is not a 'free speech situation'. However, the criminalisation of football fans is a serious restriction upon the freedom of expression and behaviour. This is a form of expression that many people may disapprove of, but historically in a liberal society, disapproval did not lead to arrests and imprisonment.

The new intolerant tolerance jars with those accustomed to heated banter. Having talked to old football fans at Ibrox, many simply don't understand the problem. Why on Earth would shouting stuff at a football game become a big deal or a political problem? 'Water off a duck's back', they say, shrug their shoulders and look puzzled. However, the idea of being able to ignore offensive comments or songs as 'water off a duck's back' is no longer the appropriate moral standpoint. Showing your outrage at intolerance and showing that you are offended becomes a 'good'. To be thin-skinned, to complain to the police, to be shocked and outraged become part and parcel of the correct form of behaviour.

But of course, once offensiveness has been criminalised the trend is for more and more things to be defined as offensive and for more fans to demand their right to tell tales on one another. On Radio Scotland recently a debate sprung up between a Celtic fan and the ex-chair of the Scottish Police Federation, Les Gray. The fan had been outraged by Motherwell fans singing about 'paedo-priests' and calling Celtic supporters Jimmy Saville. Having complained about this to a policeman at the ground he was informed that nothing could be done because this wasn't a sectarian offence. He's wrong shouted Les Gray, 'they should get the jail for singing that'.

Be warned, a right thinking man has spoken. 


\section{Bibliography}

Brick, C. (2000) 'Taking Offence', in Soccer and Society. Vol. 1, Issue. 1.

Bruce, S., Glendinning, T., Paterson, I. and Rosie, M. (2004) Sectarianism in Scotland. Edinburgh: Edinburgh University Press.

Flint, J. (2008) Governing Sectarianism in Scotland. Scottish Affairs. No. 63, spring, pp. 120-137.

Furedi, F. (2011) On Tolerance: A Defence of Moral Independence. London: Continuum

Garland, J. and Rowe, Michael. (1999) 'Policing Racism at Football Matches', in International Journal of the Sociology of Law. Vol. 27.

Giulianotti, R., Bonney, N. \& Hepworth, M. (1994) Football Violence and Social Identity. London: Routledge.

Kyriakides, C. \& Torres, R. (2012) 'The Allure of race: From New Lefts to New Times', in New Political Science. Vol. 31:1, pp. 55-80.

Kyriakides, C. (2008) 'Third Way Anti-Racism', in Ethnic and Racial Studies. Vol. 31, No. 3, pp.592-610.

Marx, K. (1970) The German Ideology. London: Lawrence and Whishart.

McArdle, D. (2000) From Boot Money to Bosman: Football Society and the Law. London: Cavendish.

Mill, J. S. (1998) On Liberty and other Essays. Oxford: Oxford University Press.

Voltaire (1924) The Philosophical Dictionary translated by H. I. Woolf. New York: Knopf.

Waiton, S. (2008) The Politics of Antisocial Behaviour: Amoral Panics. London: Routledge.

Žižek, S. (2009) Violence. London: Profile. 


\section{Endnotes}

\footnotetext{
${ }^{1}$ For example: Discussing the lawmakers' decisions to 'target Scottish football fans', Kevin McKenna argued that the act meant that 'Scotland's commitment to the human rights of its own citizens has now become a little tawdry and diminished' (Observer $18^{\text {th }}$ December 2011). Similarly, Iain MacWhirter, outraged by the act, explained that: 'Outlawing the singing of songs at football matches seemed such a ridiculous proposition that initially I thought the Scottish Government weren't serious. That Alex Salmond just wanted to 'send a message', and that the loopier parts of this unnecessary legislation would be dropped. And if not, MSPs would realise that such a law is as unworkable as it is objectionable. Surely, reason would prevail. It hasn't' (Herald $15^{\text {th }}$ December 2011).

${ }^{2}$ See the Equalities and Human Rights Commission submission to the Scottish Parliament's Justice Committee available online at:

http://www.scottish.parliament.uk/S4_JusticeCommittee/Inquiries/OB23._Equality_and_Human_Right s_Commission_Scotland.pdf

${ }^{3}$ See http://www.scotland.gov.uk/News/Releases/2011/06/17085318

${ }_{5}^{4}$ See http://www.bbc.co.uk/news/uk-scotland-glasgow-west-15333744

${ }^{5}$ See http://www.spiked-online.com/index.php/site/article/11179/

${ }^{6}$ See http://www.spiked-online.com/index.php/site/article/10861/

${ }^{7} \mathrm{See}$ www.spiked-online.com/index.php/site/article/1836

${ }^{8}$ See www.spiked-online.com/index.php/site/article/10861

${ }^{9}$ See www.spiked-online.com/index.php/site/article/11947

${ }^{10}$ See www.spiked-online.com/index.php/site/article/10861

${ }^{11}$ See http://www.spiked-online.com/index.php/site/printable/12064/

${ }^{12}$ See http://www.petitiononline.com/1967a/petition.html

${ }^{13}$ See Chapter 5 of Furedi's On Tolerance where many of the other points raised here are discussed.

${ }^{14}$ Ironically, it is also, in part, an asocial, atomised and individuated concern, generated more by our own fragmented and insecure desire to be left alone and not troubled by other people, than having anything to do with a collective form of solidarity with different ethnic groups.

${ }^{15}$ See for example the BBC1 Panorama programme Stadiums of Hate, that wrongly predicted the European Championship of 2012 would see a mass of racist violence and offensiveness.
} 